\title{
Monitoring of Wastewater Quality from Laundry and Car Wash Industries at Batu Pahat, Johor
}

\author{
A. Abu Bakar ${ }^{1}$, N. H. Hashim ${ }^{2} *$ \\ ${ }^{1,2}$ Faculty of Engineering Technology, University Tun Hussein Onn Malaysia, 84600 Panchor, Johor, Malaysia \\ *Corresponding author E-mail: haslina@uthm.edu.my
}

\begin{abstract}
The complexity of environmental chemical exposure become a major concern because an essential objective of the global research effort is to improve life quality feature. Currently, environmental monitoring has become even more critical as human population increase, with the increasing strains on the environment. The unwanted synthetic compounds that presence from grey water in natural water was lead a toxic effect on ecosystems thus may lead to changes in biodiversity. This paper aims to discuss the studies of characterization in the environmental water sample from greywater which were laundry wastewater and car wash wastewater in the area surrounding Batu Pahat, Johor, Malaysia. The samples were directly brought to the laboratory for analysis and the content of grey water quality was characterized by using physicochemical analyses including $\mathrm{pH}$, conductivity, suspended solids, chemical oxygen demand (COD), anionic surfactants (AS), oil and grease, sulfate, chloride, nitrate, and nitrite. All parameters were tested according to the standard method (APHA 2012). The result of this studies showed that the concentrations of AS by using methylene blue active substances (MBAS) were higher in laundry wastewater compared to car wash wastewater which was maximum at $105.0 \mathrm{mg} / \mathrm{L}$. While the COD for car wash wastewater was maximum at $531.1 \mathrm{mg} / \mathrm{L}$ which was higher than laundry wastewater. Some of the characterizations indicated high values for many parameters and there is the need for specific treatment prior to discharge to before it has been directly discharged to the drainage.
\end{abstract}

Keywords: Anionic surfactants; car wash; grey water; laundry.

\section{Introduction}

The extraordinary development has led to a negative impact of the global environmental changes with the complexity of environmental chemical exposure in water pollution around the regions of the country [1]. The suspended solid which are contains untreated and residue pollutant from grey water were discharge to the drainage and forming a sediment. Sediments in waterways travel downstream in suspension and the excessive sediments deposits on the river or streambed thus, catchment and deteriorated river capacity. As a consequence, the water level of river beds has risen and will increase the magnitude of flooding thus reduced the volumes of clean water and also limiting the availability of freshwater supplies [2].

Grey water typifies $43 \%$ to $70 \%$ of total domestic wastewater volume, and reusing greywater for irrigation may have adverse long-term impacts on soil [3]. Basically, grey water can be defined as wastewater without any input from the toilets which commonly are includes sources from baths, hand basins, showers, washing machines, dishwashers and kitchen sinks but excludes streams from toilets [4]. The activity of laundry, car washing, dishwashers and kitchen sinks from restaurants has also led the effluent to the grey water which is directly discharged to the drainage. The unwanted synthetic compounds which generated from grey water in natural water as a result of the living habits of society and ecosystem and may lead to the changes in biodiversity [5]. The remain of the unwanted synthetic compound to the environment can reach the freshwater, marine, and terrestrial compartments.

The number of total vehicles in Malaysia are increased year by year due to the increase in population (Malaysia population in
2018: 32.4 million people) and also the economic status of people [6]. In the year of 1980, the first recorded of total vehicles produced and assembled in Malaysia by Malaysia Automotive Association (MAA) are only 104,227 units [7]. As stated by statistic of car industry in Malaysia, the number of passenger and commercial vehicles produced assembled in Malaysia is 580,124 units in year of 2016, 576,635 units in year of 2017 and in the first half of 2018 (between January and June) is 280,947 units. The unit of vehicles in Malaysia are increased on the road thus, with the existing number of cars would definitely further boost the car wash service industry. Basically, a car wash is defined as a service of the nondomestic installation for external cleaning of cars [8]. However, car wash generates huge quantity of wastewater effluent with approximately 150 to 600 liters of wastewater per car during washing cars yields [9]. The untreated effluents discharged to the stormwater consists of several residues, such as oil and grease leaking during engine washing, high suspended solids from brake linings, with sand and dust being washed away and trace amounts of detergent-rich (surfactant) which are hardly degraded in environment [10].

Laundry can be defined as a removal by water or aqueous surfactant solution of low soluble matter and the dissolution of watersoluble impurities from the textile surface. The laundry wastewater effluent is problematic byproduct which has the potential for causing a number of undesirable effects in sewage treatment plants and in the environment. Laundry wastewater contains varying levels of suspended solids, salts, nutrients, organic matter and pathogens that arise from clothes and laundry detergents and fabric softener residues [11].

The grey water of laundry and car wash wastewater effluent are higher in both inorganic and physical pollutant compared to 
mixed grey water since it may contain a synthetic pollutant from detergent and mixed dirt or grime. Some of unwanted element pollution discharges to the grey water from washing activity containing surfactants are not biodegradable and has caused severe changes to biota with an ability to bind to bioactive macromolecules and change their biological functions [12]. The presence of synthetic compounds from grey water in natural waters has led to aesthetic losses which can cause the toxic effects at the same time give the negative implication to the ecosystems [11]. Laundry and car wash wastewater effluent contains varying levels of suspended solids, salts, nutrients, inorganic compounds, organic matter and pathogens that arise from clothes and laundry detergents and fabric softener residues.

The problem of limited freshwater supplies will be more apparent in densely populated areas with high water demand. The intense population growth is not accompanied by infrastructure improvements, especially in the field of sanitation is currently a subject of a great challenge treatment of laundry and car wash wastewater effluent. Grey water monitoring play an important role when they are evaluated for the possibility of reuse, including the need for treatment for proper discharges and meets the environmental requirements. A wide variety of technologies have been used or are being developed for grey water treatment and reuse including natural treatment systems or sewage treatment system (STP), basic coarse filtration, chemical processes, physical and physiochemical processes and biological processes. Grey water should be treated and disinfected before reuse. However, in the Malaysia grey water was discharged through the STP or discharge directly to the drainage.

The improvement of life quality level feature in our environment is needed as the monitoring and site characterization is important to society and human health also welfare.

The global environment exists as a continuum of the bio-systems and physio-chemical processes to help sustain life on earth. Therefore, environmental monitoring should ideally consist of examining the integrative nature of these processes. The basic principles of monitoring and characterization are described for different environments, considering their most relevant processes. An associated with unwanted synthetic pollution with certain risk while entering water body implies the importance of adequate analytical methods for the determination with monitoring levels in grey water of environmental water samples. The aim of this study was to provide basic data required for the characteristics of grey water wastewater which is laundry wastewater and carwash wastewater in Batu Pahat, Malaysia.

\section{Methodology}

The grey water of environmental water sample matrices was collected for monitoring purpose which were laundry wastewater and car wash wastewater at Batu Pahat, Johor. The laundry wastewater effluent was taken at collecting sample effluent of Dobi Al Hijrah, Parit Raja, Batu Pahat, Johor and car wash wastewater effluent was taken at collecting sample effluent of Bandar U Carwash, Parit Raja, Batu Pahat, Johor. Figure 1-3 show the maps and the location of collecting sample with different matric at Batu Pahat, Johor.

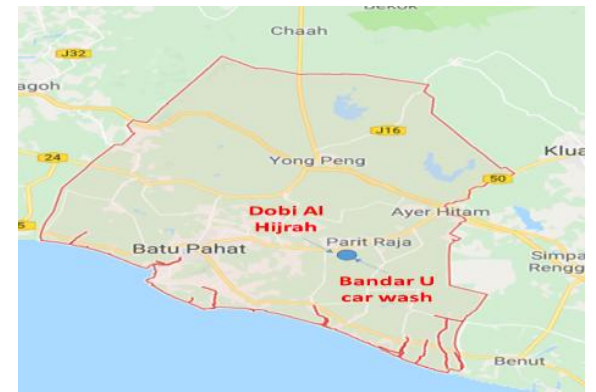

Fig. 1: Location plan of collecting sample at Batu Pahat, Johor

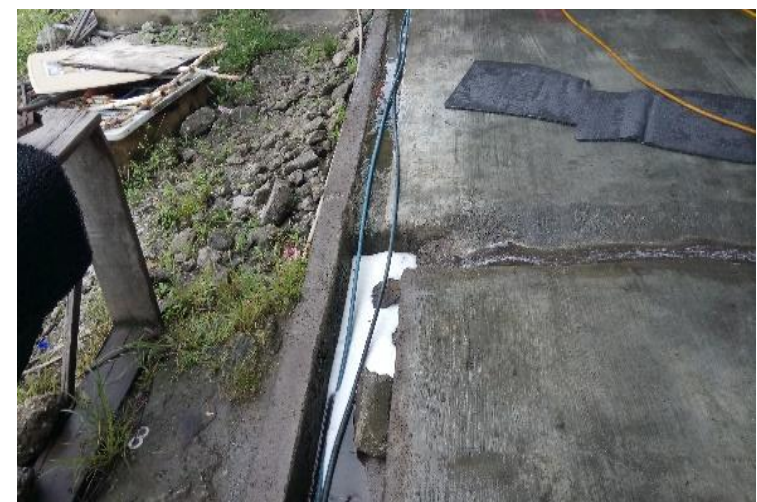

Fig. 2: Collecting sample car wash environmental water at outlet drainage of car wash wastewater

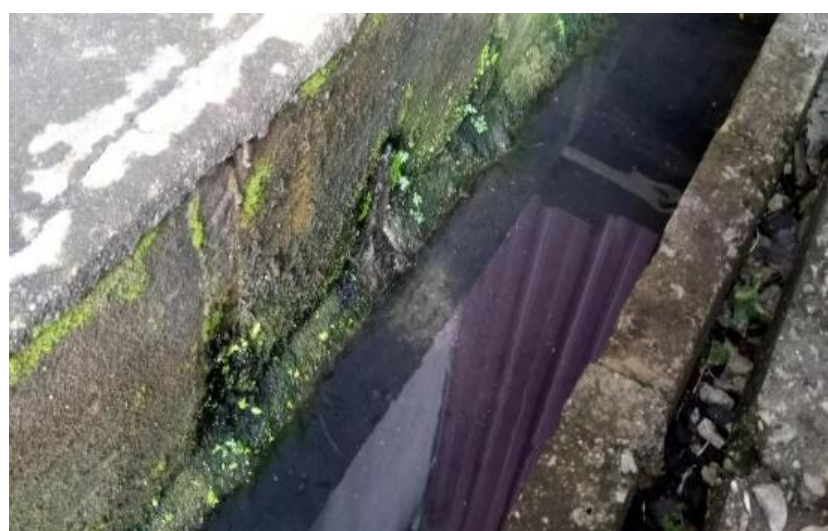

Fig. 3: Sampling location of laundry wastewater

The water samples were collected in the plastic bottle polytetrafluoroethylene (PTFE) during the dry season and kept under refrigeration $\left(4^{\circ} \mathrm{C} \pm 2{ }^{\circ} \mathrm{C}\right)$ for no longer than one week. The initial parameters of the sample such as $\mathrm{pH}$ and conductivity were determined in on site collecting sample while COD, AS, fluoride, chloride, nitrite, nitrate, bromide, orthophosphate, sulfate, and oil and grease were determined at the laboratory. The samples were directly brought to the laboratory for analysis according to the standard method (APHA 2012). All measurements were performed in triplicated. Table 1 shows the list of preservation methods by constituent.

Table 1: Preservation methods of environmental water matrices according to the standard method (APHA 2012)

\begin{tabular}{|c|c|c|}
\hline Determination & Preservation & $\begin{array}{c}\text { Regulatory } \\
\text { storage }\end{array}$ \\
\hline Conductivity & $\begin{array}{c}\text { Storage at } 4{ }^{\circ} \mathrm{C} \pm 2{ }^{\circ} \mathrm{C} \text { in the } \\
\text { dark }\end{array}$ & 28 days \\
\hline Solids & $\begin{array}{c}\text { Storage at } 4^{\circ} \mathrm{C} \pm 2{ }^{\circ} \mathrm{C} \text { in the } \\
\text { dark }\end{array}$ & 2-7 days \\
\hline $\mathrm{pH}$ & Analyse immediately & 0.25 hours \\
\hline $\begin{array}{l}\text { Chemical oxygen } \\
\text { demand (COD) }\end{array}$ & $\begin{array}{l}\text { Analyse as soon as possible, } \\
\text { Added } \mathrm{H}_{2} \mathrm{SO}_{4} \text { to } \mathrm{pH}<2 \text {, stor- } \\
\text { age at } 4^{\circ} \mathrm{C} \pm 2{ }^{\circ} \mathrm{C} \text { in the dark }\end{array}$ & 28 days \\
\hline $\begin{array}{l}\text { Anionic surfac- } \\
\text { tants (MBAS) }\end{array}$ & $\begin{array}{c}\text { Storage at } 4^{\circ} \mathrm{C} \pm 2{ }^{\circ} \mathrm{C} \text { in the } \\
\text { dark }\end{array}$ & Not stated \\
\hline Fluoride & None required & 28 days \\
\hline Chloride & None required & 28 days \\
\hline Nitrite & $\begin{array}{c}\text { Analyse as soon as possible, } \\
\text { Storage at } 4^{\circ} \mathrm{C} \pm 2{ }^{\circ} \mathrm{C} \text { in the } \\
\text { dark }\end{array}$ & $\begin{array}{l}48 \text { hours ( } 28 \\
\text { days for chlorin- } \\
\text { ated samples) }\end{array}$ \\
\hline Nitrate & $\begin{array}{l}\text { Analyse as soon as possible, } \\
\text { Added } \mathrm{H}_{2} \mathrm{SO}_{4} \text { to } \mathrm{pH}<2 \text {, Stor- } \\
\text { age at } 4^{\circ} \mathrm{C} \pm 2{ }^{\circ} \mathrm{C} \text { in the dark }\end{array}$ & 28 days \\
\hline Bromide & None required & 28 days \\
\hline Orthophosphate & $\begin{array}{c}\text { Added } \mathrm{H}_{2} \mathrm{SO}_{4} \text { to } \mathrm{pH}<2, \text { Stor- } \\
\text { age at } 4^{\circ} \mathrm{C} \pm 2^{\circ} \mathrm{C} \text { in the dark }\end{array}$ & Not stated \\
\hline Sulfate & $\begin{array}{c}\text { Storage at } 4^{\circ} \mathrm{C} \pm 2{ }^{\circ} \mathrm{C} \text { in the } \\
\text { dark }\end{array}$ & 28 days \\
\hline
\end{tabular}


The main problem in the analysis of AS is that they tend to concentrate at all interfaces due to their amphiphilic nature. Consequently, losses from aqueous solutions occur because of adsorption of the surfactants to laboratory apparatus or suspended particles. Irrespective of the surfactants to be determined, water samples are immediately preserved upon collection by the addition of formaldehyde up to a concentration of $1 \%$ and stored at $4^{\circ} \mathrm{C}$ in the dark in order to prevent adsorption of surfactant to laboratory apparatus

In this study, $\mathrm{pH}$ and conductivity was measured using portable $\mathrm{pH}$ and conductivity meter (Hanna USA). The organic compounds testing of chemical oxygen demand (COD) was followed APHA $5220 \mathrm{D}$ procedure and digested using COD reactor of $\mathrm{HACH}$ DRB 200 for 2 hours before undergoes titration method on samples. The oil and grease $(O \& G)$ concentration parameter were measured according to modified APHA $5520 \mathrm{~B}$ using extraction followed by evaporation method. Method Ion Chromatography with Chemical Suppression of Eluent Conductivity with number of method $4110 \mathrm{~B}$ used to characterized anions such as fluoride, chloride, nitrite, nitrate, bromide, orthophosphate and sulfate by using Dionex ICS-2000 of Ion Chromatography system. The determination of AS was characterize by method of Anionic Surfactant as MBAS and the number of method APHA $5540 \mathrm{C}$. All tests were conducted at the Wastewater Laboratory, Universiti Tun Hussein Malaysia, according to the Standard Method of Water and Wastewater (APHA 2012).

\section{Result}

The environmental water sample were take throughout the study for 12 months. The parameter was characterized in laundry and car wash wastewater effluent (Table 2 and Table 3 ).

The result of the studies found that laundry wastewater $\mathrm{pH}$ range of $7.1-7.5$ while car wash wastewater was higher at $\mathrm{pH}$ range 7.0 -10.5. $\mathrm{pH}$ in car wash wastewater was tested to be alkaline, this is because of the mixture of strong detergent in cleaning agent and coating agent. According to the Malaysian Environmental Quality (Sewage and Industrial Effluents), the proper $\mathrm{pH}$ value for effluen ranges from 5.5 to 9.0 for Standard B and 6.0 to 9.0 for Standard A. The average value for both laundry and car wash wastewater which recorded in this study fits within this standard, although a maximum value of car wash had a $\mathrm{pH}$ above the allowed value. Basically, $\mathrm{pH}$ in grey water is directly related to the value in the water supply. However, certain chemicals, such as fabric softeners, bleach, and disinfectant, may contribute to the variation of $\mathrm{pH}$ [11]. The characterized of $\mathrm{pH}$ is important when attempting to treat grey water, whereas lowering the range of $\mathrm{pH}$ can harm the microorganisms which responsible for organic matter degradation.

Table 2: Physico-chemical parameters of laundry wastewater effluent

\begin{tabular}{|l|c|c|c|c|c|}
\hline \multirow{2}{*}{$\begin{array}{c}\text { Parameter } \\
\left(\mathbf{m g} \cdot \mathbf{L}^{-\mathbf{1}}\right)\end{array}$} & Max & Min & Average & \multicolumn{2}{c|}{$\begin{array}{c}\text { Standard } \\
\text { permission } \\
\text { ranges* }\end{array}$} \\
\cline { 5 - 7 } & & & & $\mathrm{A}$ & $\mathrm{B}$ \\
\hline $\mathrm{pH}$ & 7.500 & 7.100 & 7.300 & $6.0-$ & $5.5-$ \\
Conductivity & 1.170 & 0.570 & 0.870 & - & 9.0 \\
$\left(\mathrm{~ms} . \mathrm{cm}^{-1}\right)$ & & & & - & - \\
TSS & 66.667 & 33.333 & 50.000 & 50 & 100 \\
TDS & 1000.000 & 566.667 & 783.334 & - & - \\
COD & 249.556 & 200.667 & 225.112 & 50 & 100 \\
AS & 105.000 & 6.200 & 55.600 & - & - \\
Fluoride & 0.376 & 0.322 & 0.349 & - & - \\
Chloride & 31.019 & 22.025 & 26.522 & 1.0 & 2.0 \\
Nitrite & 0.465 & - & 0.233 & - & - \\
Nitrate & 0.551 & - & 0.276 & - & - \\
Bromide & - & - & - & - & - \\
Orthophosphate & 9.579 & - & 4.790 & - & - \\
Sulfate & 387.437 & 116.228 & 251.833 & - & - \\
\hline
\end{tabular}

* Environmental Quality Act 1974, Environmental Quality (Sewage and Industrial Effluents) Regulations 1978.
Table 3: Physico-chemical parameters of car wash wastewater effluent

\begin{tabular}{|c|c|c|c|c|c|}
\hline \multirow[t]{2}{*}{$\begin{array}{c}\text { Parameter } \\
\left(\mathbf{m g} \cdot \mathbf{L}^{-1}\right)\end{array}$} & \multirow[t]{2}{*}{ Max } & \multirow[t]{2}{*}{ Min } & \multirow[t]{2}{*}{ Average } & \multicolumn{2}{|c|}{$\begin{array}{c}\text { Standard } \\
\text { permission } \\
\text { ranges* }\end{array}$} \\
\hline & & & & $\mathrm{A}$ & $\mathrm{B}$ \\
\hline $\mathrm{pH}$ & 10.500 & 7.000 & 8.750 & $\begin{array}{l}6.0- \\
9.0\end{array}$ & $\begin{array}{l}5.5- \\
9.0\end{array}$ \\
\hline $\begin{array}{l}\text { Conductivity } \\
\left(\mu \mathrm{s} . \mathrm{cm}^{-1}\right)\end{array}$ & 4.760 & 0.180 & 2.470 & - & - \\
\hline TSS & 422.222 & 483.333 & 452.778 & 50 & 100 \\
\hline TDS & 261.111 & 50.000 & 155.556 & - & - \\
\hline COD & 531.113 & 185.333 & 358.223 & 50 & 100 \\
\hline AS & 83.000 & 40.350 & 61.675 & - & - \\
\hline Fluoride & 0.439 & 0.349 & 0.394 & - & - \\
\hline Chloride & 23.921 & 15.350 & 19.636 & 1.0 & 2.0 \\
\hline Nitrite & 0.448 & - & 0.224 & - & - \\
\hline Nitrate & 3.454 & - & 1.727 & - & - \\
\hline Bromide & - & - & - & - & - \\
\hline $\begin{array}{l}\text { Orthophos- } \\
\text { phate }\end{array}$ & 13.947 & 3.376 & 8.662 & - & - \\
\hline Sulfate & 21.329 & 13.970 & 17.650 & - & - \\
\hline
\end{tabular}

* Environmental Quality Act 1974, Environmental Quality (Sewage and Industrial Effluents) Regulations 1978.

Conductivity is an ability depends on the presence of ions on the total concentration of solution, mobility, valence and on the temperature measurement. Most of inorganic compounds in the solution are relatively good conductor element. On the other hand, molecules of organic compounds which does not dissociate in aqueous solution has very poor conductivity element to conduct current. The conductivity of laundry wastewater was observed at average $0.8 \mathrm{~ms} . \mathrm{cm}^{-1}$. Meanwhile, the conductivity of car wash wastewater was higher compared to laundry wastewater at 2.47 $\mathrm{ms} . \mathrm{cm}^{-1}$. This is due to the amount of conductor element in inorganic compound at the car wash was higher compared to the laundry waste water. However, the conductivity of laundry wastewater in the previous research was higher at range 2.01-5.75 ms. $\mathrm{cm}^{-1}[13]$. Whereas, car wash wastewater of previous studies was lower compared to this research which were at range 0.15 $0.26 \mathrm{~ms} . \mathrm{cm}^{-1}$ [14]. This is because it's depends on the many influence such as mixing of the chemical compounds in the detergent that being used, the hardness of the water, and the dirt on the textile or at vehicle.

In this study, the organic compounds both laundry and car wash wastewater were characterized by COD parameter. COD was observed to be lower in laundry wastewater which is at average $225.11 \mathrm{mg} \cdot \mathrm{L}^{-1}$ compared to car wash wastewater which at average $358.22 \mathrm{mg} \cdot \mathrm{L}^{-1}$. Based on Malaysian legislation, the average values of COD for both laundry and car wash wastewater which recorded in this study does not fits within this Standard B which is must below $100 \mathrm{mg} \cdot \mathrm{L}^{-1}$. A pollutants characterization of car wash wastewater were studied [10]. The authors found the values were above those found in this study which is $485 \mathrm{mg} \cdot \mathrm{L}^{-1}$ of COD. Then, the average values of TSS content in laundry wastewater was $50.0 \mathrm{mg} \cdot \mathrm{L}^{-1}$. Instead, the average values of TSS in car wash are much higher which was $452.8 \mathrm{mg} \cdot \mathrm{L}^{-1}$. Measures of TSS have been reported in the literature in a range of $0.12-290 \mathrm{mg} \cdot \mathrm{L}^{-1}$ in laundry [15], [11]. Meanwhile, TSS in car wash has been reported in the literature in a range $68.0-4887 \mathrm{mg} \cdot \mathrm{L}^{-1}$ [16], [17]. The high levels of both soluble COD and TSS in car wash compared to laundry are due to the use of COD and TSS comes from the use of non-biodegradable surfactant with dirt and oil including both organic and inorganic compounds during car washing are more than in laundry wastewater. The low suspended solids concentration in the laundry wastewater has indicating that a large portion of the contaminants in the dissolved form [18]. Inevitably, the average values of TDS in laundry wastewater was higher compared to TDS from car wash wastewater in this research which were $783.34 \mathrm{mg} \cdot \mathrm{L}^{-1}$ of laundry wastewater and car wash wastewater at 
$155.56 \mathrm{mg} \cdot \mathrm{L}^{-1}$. As a matter of fact, previous studies shows the low suspended solids found in grey water are partially explained by the size distribution data which reveals the particles to be mainly within the 10 to $100 \mu \mathrm{m}$ range (volume weighted) and the laundry wastewater is made up of molecules similar in size to humic and fulvic compounds which in dissolve solid [4].

Fluoride is ubiquitous and found in the environment is derived from both natural and anthropogenic sources. In this studies, fluoride found from laundry wastewater in average values of 0.35 $\mathrm{mg} \cdot \mathrm{L}^{-1}$ and car wash wastewater was in average values of 0.394 $\mathrm{mg} \cdot \mathrm{L}^{-1}$. Fluoride can cause injury to susceptible plants at concentrations below $1 \mathrm{ppb}\left(0.8 \mathrm{mg} \cdot \mathrm{m}^{-3}\right)$ for exposure periods of 7 days or less. Exposure to fluoride can result in marked increases in foliage fluoride levels. The extent of increases depends upon factors such as duration of exposure, atmospheric fluoride levels, and species or variety of plants. Fluoride induced effects in plants may be viewed based on four levels of biologic organization: cellular, tissue or organ, organism, and ecosystem.

Among the nitrogen compound, nitrate had the greatest contribution in car wash wastewater which was found with a maximum value at $3.45 \mathrm{mg} \cdot \mathrm{L}^{-1}$, while nitrate in laundry wastewater compared to be lower with a maximum value at $0.55 \mathrm{mg} \cdot \mathrm{L}^{-1}$. The maximum values of nitrite from both laundry and car wash wastewater was observed lower than nitrate maximum values which were $0.47 \mathrm{mg} \cdot \mathrm{L}^{-1}$ and $0.45 \mathrm{mg} \cdot \mathrm{L}^{-1}$ respectively. The nitrate in the commercials laundry wastewater have been observe in the literature in range $1.03-25.7 \mathrm{mg} \cdot \mathrm{L}^{-1}$ while the nitrite was at range 1.1-3.3 $\mathrm{mg} \cdot \mathrm{L}^{-1}[11]$. The values of both nitrite and nitrate in this monitoring are in the range by previous studies of commercials laundry wastewater. There has been an imposed of a limit by 10 $\mathrm{mg}$ nitrate as nitrogen/L on drinking water to prevent the contribution of illness known as methemoglobinemia in infants. During nitrifying, nitrate can be found much higher concentration up to 30 $\mathrm{mg}$ nitrate as nitrogen/L. This is an essential nutrient for may photosynthetic autotrophs. For both reactions in the oxidation of ammonia to nitrate and in the reduction of nitrate, nitrite has become an intermediate oxidation state of nitrogen. The intermediate oxidation state of nitrogen has very fast reaction thus, nitrite values is lower due to its oxidation and reduction process changes of nitrate. AS average values from laundry and car wash wastewater were found in this study which were 55.6 and $61.67 \mathrm{mg} \cdot \mathrm{L}^{-1}$ respectively Previous research has measured AS by using MBAS method from laundry wastewater which were in a range $5.7-11.8 \mathrm{mg} \cdot \mathrm{L}^{-1}[13]$. Many countries have listed AS in permission range in their country. For example, according to the World Health Organization (WHO), anionic detergent limit of drinking water is under 0.2 $\mathrm{mg} \cdot \mathrm{L}^{-1}$. Meanwhile, the European Union wastewater quality criteria have the reference level of as methylene blue active agents which is at $\leq 0.3 \mathrm{mg} \cdot \mathrm{L}^{-1}[19]$. AS is not listed in permission range of environmental quality regulations sewage and industrial effluent in Malaysia but in anyhow, AS has been listed of parameters for a discharge of industrial effluent or mixed effluent which best management practice to be adopted or specified in Malaysia.

\section{Conclusion}

From this study, it can be concluded that there is an urgent need for more information about the characteristics of grey water focusing monitoring of laundry and car wash wastewater. The commercial laundry and car wash wastewater studied had no consistent characteristics, and the content of study parameters varied from sample to sample and some of them depend on the influent of other factor. Some of the characterizations indicated high values of concentration for the permissible limit of standard A and standard B by the Malaysia Environmental Quality (Sewage and Industrial Effluents). Thus, there is a needed for specific treatment prior before it has been directly discharged to the drainage. This future work might have led to the suitable treatment for grey water to discharge to the drainage with the standard permissible of environment quality.

\section{Acknowledgement}

This work was financed by the Ministry of Higher Education of Malaysia under the Fundamental Research Grant Scheme (FRGS) Vot No.: 1565.

\section{References}

[1] X. Y. Teh, P. E. Poh, D. Gouwanda, and M. N. Chong, "Decentralized light greywater treatment using aerobic digestion and hydrogen peroxide disinfection for non-potable reuse," J. Clean Prod., vol. 99, pp. 305-311, 2015.

[2] M. Abdul Mohit and G. Mohamed Sellu, "Development of Nonstructural Flood Mitigation Policies and Measures for Pekan town, Malaysia," Asian J. Behav. Stud., vol. 2, no. 6, p. 9, 2017.

[3] K. S. Oh, J. Y. C. Leong, P. E. Poh, M. N. Chong, and E. Von Lau, "A review of greywater recycling related issues: Challenges and future prospects in Malaysia," J. Clean. Prod., vol. 171, pp. 17-29, 2018.

[4] B. Jefferson, A. Palmer, P. Jeffrey, R. Stuetz, and S. Judd, "Grey water characterisation and its impact on the selection and ioperation of technologines for urban reuse.pdf," Water Sci. Technol., vol. 50, no. 2 , pp. $157-164,2004$

[5] F. Li, K. Wichmann, and R. Otterpohl, "Review of the technological approaches for grey water treatment and reuses," Sci. Total Environ., vol. 407, no. 11, pp. 3439-3449, 2009

[6] "Deparment of statistics Malaysia." [Online]. Available: https://newss.statistics.gov.my/. [Accessed: 19-Aug-2018].

[7] "Malaysian Automotive Association." [Online]. Available: http://www.maa.org.my/. [Accessed: 19-Aug-2018]

[8] K. Boussu, C. Kindts, C. Vandecasteele, and B. Van der Bruggen, "Applicability of nanofiltration in the carwash industry," Sep. Purif. Technol., vol. 54, no. 2, pp. 139-146, 2007.

[9] W. J. Lau, a. F. Ismail, and S. Firdaus, "Car wash industry in Malaysia: Treatment of car wash effluent using ultrafiltration and nanofiltration membranes," Sep. Purif. Technol., vol. 104, pp. 26$31,2013$.

[10] N. H. Hashim and N. Zayadi, "Pollutants Characterization of Car Wash Wastewater," MATEC Web Conf., vol. 08, pp. 4-9, 2016.

[11] J. K. Braga and M. B. a Varesche, "Commercial Laundry Water Characterisation," Am. J. Anal. Chem., vol. 2014, no. 5, pp. 8-16, 2014.

[12] A. Ribelles, M. C. Carrasco, M. Rosety, and M. Aldana, "A histochemical study of the biological effects of sodium dodecyl sulfate on the intestine of the gilthead seabream, Sparus aurata L.," Ecotoxicology and environmental safety, vol. 32, no. 2. pp. 131-8, 1995.

[13] S. Bering, J. Mazur, K. Tarnowski, M. Janus, S. Mozia, and A. W. Morawski, "The application of moving bed bio-reactor (MBBR) in commercial laundry wastewater treatment," Sci. Total Environ., vol. 627 , pp. $1638-1643,2018$

[14] W. J. Lau, a. F. Ismail, and S. Firdaus, "Car wash industry in Malaysia: Treatment of car wash effluent using ultrafiltration and nanofiltration membranes," Sep. Purif. Technol., vol. 104, no. November, pp. 26-31, 2013.

[15] T. P. Delforno, A. G. L. Moura, D. Y. Okada, and M. B. A. Varesche, "Effect of biomass adaptation to the degradation of anionic surfactants in laundry wastewater using EGSB reactors.," Bioresour. Technol., vol. 154, no. November, pp. 114-21, 2014.

[16] R. Zaneti, R. Etchepare, and J. Rubio, "Car wash wastewater reclamation. Full-scale application and upcoming features," Resour. Conserv. Recycl., vol. 55, no. 11, pp. 953-959, 2011.

[17] C. Fall, C. M. López-Vázquez, M. C. Jiménez-Moleon, K. M. Bâ, C. Díaz-Delgado, and M. García-Pulido, D., \& Lucero-Chavez, "Carwash wastewaters: characteristics, volumes, and treatability by gravity oil separation," 2007.

[18] O. R. Al-Jayyousi, "Greywater reuse: Towards sustainable water management," Desalination, vol. 156, no. 1-3, pp. 181-192, 2003.

[19] E. Minareci, O., Öztürk, M., Egemen, O. and Minareci, "Detergen and phosphate pollution in Gediz River, Turkey," African $J$. Biotechnol., vol. 8, no. 15, pp. 3568-3575, 2009. 